\title{
Strategic Orientations for Systemic Modernization of the Russian Federation's Social Development
}

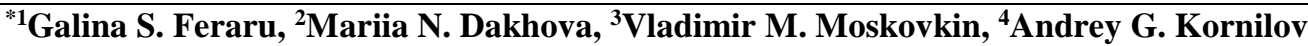 \\ 1,2,3,4 Belgorod State University, Russia, 308015, Belgorod, Pobedy st., 85 \\ *Email: feraru22@mail.ru
}

Received: 21st October 2017 Accepted: 16th November 2017, Published: 31st December 2017

\begin{abstract}
At the current stage of Russia's social and economic development the issue of systemic modernization is relevant for several reasons: the collapse of single economy after the Soviet Union disintegration caused the severance of economic relations and entities' shutdown, commodity dependence of Russian economy in continued capital scarcity inside the country and credit and financial institutions' system insufficient development, the high natural resource intensity of Russian economy, and continuing degradation of values and norms, spiritual dimensions of nation's social development violation. Analysis of main economic indicators characterizing domestic economy's level of development and structure for past two decades confirms the assumptions about the reasons of immediacy of domestic economy's systemic modernization problem. The intensity of further growth will depend upon the effectiveness of measures taken to eliminate barriers to structural changes in economy, to restructure inefficient companies and industries, to enhance the mobility in the labour market, and to create an effective institutional environment conducive to the development of entrepreneurial initiative. The challenges of public system modernization are broader than the aspects of economic modernization, since it involves the social and environmental development components. Ivan Yanzul's four principles show complexity, difficulty, and long-term nature of challenges facing Russian society. These principles could be applied to solve public modernization issues.
\end{abstract}

Keywords: Systemic Modernization, Social Development, Economy, Competitiveness, Effectiveness.

\section{Introduction}

The strategic objective of social development, which assumes the creation of smart economy satisfying the general population's interests and needs, has been formulated in the Annual Presidential Address to the Federal Assembly of the Russian Federation November 12, 2009. This objective can be achieved through systematic modernization of society covering all aspects of living environment.

The goal of this research is to propose and justify the strategic directions in systemic modernization of the Russian Federation, involving political, economic, technical and technological, and cultural aspects of societal life.

The objectives of the research are following:
1. To interpret the concept of systemic modernization;

2. To reflect causes of urgent need in systemic modernization in Russia;

3. To elaborate the key issue in the public administration and public service and to suggest the ways of their targeted institutional changes;

4. To identify and to justify the reasons for mainstreaming the issue of economy's systemic modernization and to offer solutions for its development;

5. To provide recommendations for public system modernization through the revival of cultural values.

Subject of study is a process of social development in the Russian Federation.

The concept of "modernization" requires concrete definition. Earlier theories of considered this concept as predetermined course and result of historical development, as an automatically active force of history leading societies with the different speed toward same goal. Within the framework of these paradigms, the concept of development equates with the concept of modernization, the concept of modernization with the notion of industrialization, and industrialization with dominance of heavy industry, big factories and the new production mode. According to S.N. Eisenshtadt the process of modernization is a complex of different respond of societies on specific challenges [1]. According to D.S. Gibbons, any political science cannot be proud of their contribution to concept of modernization explanation. Gibbons criticized Eisenstadt for not weighting the most important factors of modernization. Gibbons' thesis is that success in transitional countries' modernization is mainly the result of political factors. However, he does not exclude the impact of sociological factors on modernization [2].

Barrington Moore, Jr., submits that "methods of modernization chosen in one country change the dimensions of the problem for the next countries" [3]. Jorge Walter, Cecilia Senen Gonzalez divide concepts systemic modernization and revamping. According to these authors, "systemic modernization replacement of processes and products by new ones or revamping, i.e., rehabilitation and improvement of existing equipment and products" [4].

Systemic modernization involves ecological modernization. This concept was put into practice in 1980s to link the market economy development and long-term requirements of sustainable development. Generally, the concept of modernization (its economic core) is "the systematic, knowledge-based improvement of procedures and products" [5]. The latter half of the 
twentieth century was characterized by the social and economic landscape rapid changes, including modernization and significant economic development. It left the mark on contemporary socio-political and educational landscape of different countries. The development in the 1970s was described by Ingólfur Á. Jóhannesson as a systemic modernization based on democratic principles [6].

Modernizations of public sector, intergovernmental relations, implementing the local strategies of development were among the biggest challenges in transition economy countries. It involved both the central and the local level. Even now the developed countries are facing with challenges in creating efficient subnational systems.

The concept of "modernization" in economics means the renovation, eradication of underdevelopment, contemporary level of development achievement, comparable to advanced economies [7].

The concept of "systemic" in the context of "modernization" concept is interpreted as:

- Political modernization, which involves quite radical changes in political system of the country, its democratization and liberalization, constraining the role of the state in economy, etc.;

- Techno-economic modernization of enterprises and institutions, Russians` daily life. It implies the introduction of new production technologies, modern computer and information technologies, development in machinery and equipment, scientific and technological innovations in economic activities, entrepreneurship development in general and small businesses in particular, an increasing the civilized competition in all sectors of employment;

- Social modernization, which requires the significant changes in social relations area, primarily the workplace relationships, changes in education system, public sector and reform of most public institutions, changes of interpersonal agreement culture based on corruption, and development its legal framework.

At the current stage of Russia's social and economic development the issue of systemic modernization is relevant for several reasons:

1. The collapse of single economy after the Soviet Union disintegration caused the severance of economic relations, entities' shutdown, and the ensuing privatization in the Russian Federation resulted in continued output collapse, loss of high-technology products market, and lopsided natural resources sector development. Russian products were pushed out of the world markets. Plants and equipment deterioration was substantial. Whole scientific schools in the field of aircraft, shipbuilding and space industry were lost. Manufacturing investment and investment in production facilities modernization was minimal. Consequently, the innovation and technological renewal of productive base is a necessary condition for systemic modernization.

2. Commodity dependence of Russian economy in continued capital scarcity inside the country and credit and financial institutions' system insufficient development, have resulted in accumulation of investment resources in the companies operate in industries where production chains were not collapsed at all, or were these chains were so simple that they managed to be restored relatively quickly. The production facilities of the rest of the industries were hardly renovated and their technologies were not developed for decade and more. It caused the decline in competitiveness of the majority of manufacturing industries enterprises' products in comparison to foreign ones. Consequently, the provision of domestic products' quality and competitiveness is one of the basic objectives of modern Russian economic development.

3. The high natural resource intensity of Russian economy, in comparison with other countries' economic structure. For instance, the energy intensity per unit of production in Russia is 11 times higher than in Japan, 7 times higher than in Germany, and 7 times higher than in the USA. The forest resources consumption per ton of paper in Russia is 4-6 times higher than in developed countries. The land resources consumption per crop in Russian agricultural sector is 2-3 times higher than in developed counties $[8,9]$.

In situation of historical choice Russia attempted to embark on the path of catch-up modernization to transfer Western cultural and civilizational values and institutions to Russian ground to build its economy and market on liberal and classical patterns. Consequently, the systemic flaws of this economic model persist: it supports the steadily resource-intensive type of development and discourages the reduction of resource-intensity production. Consequently, the minimization of domestic economy's natural resource intensity is essential for systemic modernization [10].

4. The continuing degradation of values and norms, and violation of spiritual dimensions of nation's social development. As stated by D.S. Likhachov, who dedicated his life to study and dissemination of Russian culture, "There is no morality of society without culture, social and economic laws do not apply, the decrees are not implemented, and modern science cannot exist". At various times the answer to the question, what prevents our country from moving ahead in socio-economic terms, three famous academicians, two of those are economists of different doctrines, gave similar answers. Academician S.S. Shatalin said that there are three barriers obstacle to our countries movement ahead, "The first is an incivility in all areas, including political, social, communication, employment areas, etc. The second one is incompetence and unprofessionalism. This is about each and every of us... The third one is a dogmatic thinking" [11]. Hence, the spiritual dimension development, based on revival of morality, is essential for panned transformation of society.

Development of society is a fairly general and broad concept that includes not only economy, social as- 
pects, and performance of ecological systems, but also public institutions, technology, knowledge, legal restrictions, political system, etc. [12]. At the same time the modernization imposes the specific requirement for governance of the country to enhance the efficiency and to overcome the management and society dysfunctional states. Key issue in deliberate institutional changes in public administration and public service is a necessity to ensure the consistency between transformation of the institutional system and objective needs of society in different stages of economic and social development [13]. The representatives of establishment pay increased attention to issue of public administration effectiveness, and show the real concern over quality of government decisions and particularly their implementation in terms of significant transformation of public administration system's environment.

Modernization of economy and society is undoubtedly a systemic modernization. Stating the objective in these terms, de facto low systemic efficiency of Russian public system (if virtually all social subsystems require changes simultaneously, then there is a systemic crisis of society) and low living standards of the population, dysfunction of management system are recognized [14].

Administrative reforms can be described as policy cycle including institutional choice and institutional effects. These effects become "feedback effect" factors that influence on political system, acting as public servants' behavior models, motivations, and management practices. The lasts form qualitative parameters for government functions implementation and public services provision, i.e. a certain managerial capacity level of the state [15] .

The development of Russian authorities' institutional capacity in 2000 s was characterized by strengthening the status of the executive branch, as dominant political actor. At the same time the public service was "partially rationalized": modern legislation was elaborated; two federal reform programs were implemented (2003-2007 and 2009-2013); anti-corruption institutions were gradually developed. So far, however, "informal institutionalization" still is a dominant feature of political regime, and rent-seeking behavior persists as an important element of politicaleconomic realities.

Expert survey "The quality of public administration in regions of Russia - 2014", conducted by University of Gothenburg (Sweden) and National Research University Higher School of Economics (Russia), aimed to identify the key characteristics of public service system's institutional arrangements and the conduct of public officials in regions of Russia. This survey is based on assessments of carefully selected 466 regional experts. Geographical covering of this survey was 79 of 85 regions of Russia. The survey found that in comparison with North America and Europe, especially Eastern Europe, where biggest threat to principles of merit system and efficient bu- reaucracy comes from so-called political appointees [16], in Russia this threat has its roots in kinship or personal ties between those who are in the performance of their official duties (including politicians and civil servants), and those who wishes to enter the public service. These ties predominate in 57 of 79 regions. This suggests the existence in Russia nor merit or spoils system, but so-called patrimonial bureaucracy $[17,18]$.

The experience of catch-up modernization countries illustrates the critical need for a public administration "Weberianization" as a prerequisite for long-term "development policy" [19]. In the papers of P. Evans and J. Rauch the link between some elements' of bureaucratic rationality development and economic growth was demonstrated clearly by analytic comparison of administrative bodies activities in the large group of developing countries [20]. Firstly, it is a meritocratic hiring, relies on the combination of training and competitive selection, and predictable career ladder, providing material and non-material reward to members of bureaucratic organization for long term.

\section{Materials and Methods}

In research the complex methodology based on application of system, structural and process approaches as scientific methods for solution of systemic modernization in Russian Federation issue is used. First-hand information was processed by statistical and comparative analysis and synthesis methods.

\section{Results and Discussions}

In the civil service of the Russian Federation the separate management functions are currently allocated to different authorities (fragmented governance, "multipolar" governance). This creates a situation in which the real management center is shifted into human resources services, where the organization of public services is departmental. It hindering the consolidation of public administration, diffusing the responsibility, and depriving the independent human resources audit system of consolidated personnel policy implementation. Without fully-fledged management system (including governance institutions at the federal and local level) the probability of "partial reform trap" preservation (including predominance of protectionist practices in human resources management) still high.

Analysis of main economic indicators characterizing domestic economy's level of development and structure for past two decades confirms the assumptions about the reasons of immediacy of domestic economy's systemic modernization issue.

As seen from the data in Table 1, the natural resources sectors' share in the industrial structure of Russia in 1990-2016 increased. Simultaneously, the share of processing industries decreased, inter alia, metal-fabricating industry's share and share of consumer goods industry's declined significantly. 
Table 1: The Industrial Structure of Russia (per cent of total)*

\begin{tabular}{|c|c|c|c|c|c|}
\hline Industry & 1990 & 2000 & 2008 & 2012 & 2016 \\
\hline Industrial Output, Total & 100.0 & 100.0 & 100.0 & 100.0 & 100,4 \\
\hline Electric Utility Industry & 3.6 & 7.9 & 6.4 & \multirow{2}{*}{27.4} & 10,2 \\
\hline Fuel Industry & 6.8 & 17.5 & 19.5 & & 19,6 \\
\hline Iron and Steel Industry & 4.9 & 7.1 & \multirow{2}{*}{13.3} & \multirow{2}{*}{10.7} & 8,2 \\
\hline Nonferrous Metals Industry & 5.4 & 8.7 & & & 8,3 \\
\hline Chemical and Petrochemical Industry & 6.9 & 6.2 & 7.0 & 6.8 & 6,6 \\
\hline Metal-fabricating Industry & 28.0 & 16.4 & 13.8 & 14.6 & 13,5 \\
\hline Forest, Pulp and Paper and Woodworking Industries & 5.2 & 4.0 & 3.3 & 2.8 & 4,5 \\
\hline Construction Materials Industry & 3.4 & 2.4 & 4.1 & 2.9 & 2,6 \\
\hline Consumer Goods Industry & 11.0 & 1.4 & 0.7 & 0.7 & 1,5 \\
\hline Food Processing Industry & 12.1 & 11.1 & 10.8 & 10.6 & 13,4 \\
\hline
\end{tabular}

*References. [21]

The labor productivity in the majority of industries decreased (Table 2).

Table 2: Index of Labor Productivity in Main Sectors of Russian Economy (under the Russian Classification of Economic Activities)*

\begin{tabular}{|c|c|c|c|c|}
\hline & 2005 & 2010 & 2015 & 2016 \\
\hline Whole Economy & 105.5 & 103.2 & 96.8 & 97.8 \\
\hline Agriculture, Hunting and Forestry & 101.8 & 88.3 & 105.0 & 104.9 \\
\hline Fisheries and Aquaculture Sectors & 96.5 & 97.0 & 98.1 & 99.5 \\
\hline Mining Operation & 106.3 & 104.3 & 99.3 & 98.4 \\
\hline Manufacturing & 106.0 & 105.2 & 96.5 & 96.9 \\
\hline Electricity, Gas and Water Production and Distribution & 103.7 & 103.0 & 100.0 & 99.9 \\
\hline Construction & 105.9 & 99.6 & 95.4 & 101.0 \\
\hline $\begin{array}{l}\text { Wholesale and Retail Trade, Motor Vehicle, Household Goods, and Personal } \\
\text { Demand Items Repair }\end{array}$ & 105.1 & 103.6 & 90.3 & 91.5 \\
\hline Restaurants and Hotels & 108.5 & 101.7 & 93.3 & 94.1 \\
\hline Transport and Communication & 102.1 & 103.2 & 99.0 & 99.4 \\
\hline Real Estate Operations, Rent, Service Delivery & 112.4 & 104.0 & 95.7 & 97.2 \\
\hline
\end{tabular}

* References. [21]

Wear and tear of fixed assets, representing the material and technical facilities of industries, increased (Table 3).

Table 3: Wear and Tear of Fixed Assets in Main Sectors of Russian Economy (at full cost, at mixed prices),

\begin{tabular}{|l|c|c|c|c|c|c|c|c|c|}
\hline \multicolumn{1}{|c|}{ Economic Activities } & $\mathbf{2 0 0 8}$ & $\mathbf{2 0 0 9}$ & $\mathbf{2 0 1 0}$ & $\mathbf{2 0 1 1}$ & $\mathbf{2 0 1 2}$ & $\mathbf{2 0 1 3}$ & $\mathbf{2 0 1 4}$ & $\mathbf{2 0 1 5}$ & $\mathbf{2 0 1 6}$ \\
\hline Fixed Assets, total & $\mathbf{4 3 . 4}$ & $\mathbf{4 4 . 3}$ & $\mathbf{4 5 . 7}$ & $\mathbf{4 6 . 3}$ & $\mathbf{4 6 . 0}$ & $\mathbf{4 6 . 5}$ & $\mathbf{4 7 . 3}$ & $\mathbf{4 8 . 2}$ & $\mathbf{4 8 . 8}$ \\
\hline Agriculture, Hunting and Forestry & 37.6 & 37.9 & 38.1 & 37.3 & 38.2 & 38.8 & 39.7 & 40.7 & 41.1 \\
\hline Mining Operation & 45.6 & 45.9 & 46.8 & 48.4 & 49.6 & 52.3 & 53.0 & 52.8 & 47.5 \\
\hline Manufacturing & 41.0 & 41.2 & 42.2 & 42.6 & 43.4 & 43.6 & 44.7 & 45.9 & 54.9 \\
\hline $\begin{array}{l}\text { Electricity, Gas and Water Production and } \\
\text { Distribution }\end{array}$ & 40.1 & 41.7 & 42.0 & 42.0 & 39.3 & 39.2 & 39.6 & 40.2 & 47.4 \\
\hline Construction & 37.4 & 41.6 & 42.4 & 39.9 & 43.9 & 46.3 & 46.4 & 45.1 & 41.7 \\
\hline $\begin{array}{l}\text { Wholesale and Retail Trade, Motor Vehi- } \\
\text { cle, Household Goods, and Personal De- } \\
\text { mand Items Repair }\end{array}$ & 60.8 & 61.6 & 63.7 & 63.7 & 61.8 & 62.2 & 62.3 & 63.6 & 47.7 \\
\hline Transport and Communication & 33.6 & 36.3 & 37.0 & 38.8 & 40.3 & 40.8 & 43.2 & 44.4 & 64.2 \\
\hline Finance & 30.4 & 34.4 & 33.9 & 32.8 & 33.2 & 33.7 & 37.1 & 39.0 & 30.4 \\
\hline $\begin{array}{l}\text { Real Estate Operations, Rent, Service De- } \\
\text { livery }\end{array}$ & 36.8 & 38.0 & 38.9 & 37.7 & 36.5 & 35.6 & 42.8 & 44.7 & 44.9 \\
\hline Education & 44.9 & 47.3 & 48.1 & 47.2 & 47.3 & 47.1 & 47.3 & 46.1 & 36.3 \\
\hline Public Health and Social Services & 44.5 & 44.6 & 45.5 & 46.0 & 45.4 & 46.7 & 47.7 & 49.9 & 43.9 \\
\hline $\begin{array}{l}\text { Provision of other communal, social and } \\
\text { personal services }\end{array}$ & 26.7 & 28.7 & 38.3 & 36.9 & 38.0 & 39.3 & 39.2 & 39.9 & 39.5 \\
\hline
\end{tabular}

* References. [21] 
At the same time, raw materials export almost doubled during the survey period. Export of machinery and equipment fell almost three times. At the same time raw materials import decreased, and machinery and equipment import increased (Table 4).

Table 4. Export and Import Pattern of the Russian Federation (per cent of total)*

\begin{tabular}{|c|c|c|c|c|c|c|c|c|c|c|c|c|c|}
\hline \multirow{2}{*}{$\begin{array}{l}\text { Family Group of } \\
\text { Goods }\end{array}$} & \multicolumn{6}{|c|}{ Export, by year } & \multicolumn{7}{|c|}{ Import, by year } \\
\hline & 1990 & 1995 & 2000 & 2005 & 2008 & 2014 & 1990 & 1995 & 2000 & 2005 & 2008 & 2014 & 2015 \\
\hline $\begin{array}{l}\text { Machinery and } \\
\text { Equipment, Vehicles }\end{array}$ & 18.3 & 10.2 & 8.8 & 5.6 & 4.9 & 5.3 & 44.8 & 33.6 & 31.4 & 44.0 & 52.7 & 47.6 & 47.4 \\
\hline Mineral Commodity & 40.5 & 42.5 & 53.8 & 64.8 & 69.6 & 70.5 & 2.6 & 6.4 & 6.3 & 3.1 & 3.1 & 2.6 & 1.3 \\
\hline $\begin{array}{l}\text { Precious metals, gem } \\
\text { stones, and article } \\
\text { made therefrom }\end{array}$ & 11.3 & 26.7 & 21.7 & 16.8 & 13.3 & - & 5.1 & 8.5 & 8.3 & 7.7 & 7.3 & - & 6.6 \\
\hline
\end{tabular}

* References. [21]

In other words, the "raw" structure of the Russian economy has developed. Share of raw materials in the gross (national) product is significant and reaches up to $65 \%$. The income of this sector also covers the majority of federal budget expenditures, maintains a positive trade balance (surplus), and provides up to $70 \%$ of the country's exports. At the same time, the efficiency of raw materials extraction is not high, the capital intensity of this production decreases. However, the "disinvestment" and extensive economic growth support cannot last because of the assets' wear out and morally obsolete [22].

Declining of the main economic indicators characterizing the structure and growth rate of economy has negative impact on domestic product's competitiveness. Experts estimate that only $8-10 \%$ of manufactured products meet international requirements [23]. Domestic economy`s comparative advantages largely are blocked by its weaknesses. Among those weaknesses are: high energy and material intensity of production, resulting in high cost of most domestic finished products; technological backwardness of many industries, that prevents from manufacturing highquality products; inadequate transport and communications infrastructure development; the incomplete economic entities' adaptation to operation under market conditions, etc.

The financial sector's divorce from the real economy and social sphere, the United States dollar currency peg, high refinancing rate, tight credit, increased profitability of financial transactions, capital flight, lack of equity's transparency, and many other elements produce scarcity of investment capital for innovative activities and industrial modernization. Economic reforms, taken as a whole, are clearly incomplete: firstly, because of closed nature and lack of transparency about the internal functioning of the State and entrepreneurship in a market environment, and secondly, as there are no rules and norms for interaction between these main systems in a competitive environment.

However, Russia can modernize its economy: it has sufficient resources and capacity, large domestic market. Russia has great capacities, including growing domestic demand, rich natural resources, favorable location, access to major world markets, high level of population's basic education, etc. By all objective indicators, Russia should be among world economic leaders and one of the most attractive countries for living and doing business.

In our view, Russian economy's systemic modernization development path should include [1]:

- structural shifts in the economy, establishment of productive structure meeting the criteria for advanced industrial country; export promotion of promising goods (through the subsidy and credit system development, public procurement, public guarantees, tariff-based and non-tariff-based measures regulating foreign trade);

- retraining, requalification or replacement of personnel, re-education and reorientation of individuals, assimilation of mentality that responds to demands of the times;

- setting up the advanced production in Russia on sufficient, to take a worthy position at international level, scale;

- mainstreaming Russia into the newest world innovative processes, full integration into the global economy, harnessing all significant innovations, including management innovations; innovative enterprises development based on catch-up and advanced technical and technological modernization of some production facilities; renovation of productive capacities, replacement of obsolete equipment and technologies by more productive modern ones; shifting the production of goods and services to internationally accepted standards and their subsequent certification;

Pricing system and pay system improvement, taking into account the international trends resulting from digitalization of business processes, changes in energy and natural resources production and consumption, and others.

The intensity of further growth will depend upon the effectiveness of measures taken to eliminate barriers to structural changes in economy, to restructure inefficient companies and industries, to enhance the mobility in the labor market, and to create an effective institutional environment, conducive to the development of entrepreneurial initiative [24].

In addition to the above, systemic modernization implies environmentally sustainable economic reforms, 
considering level and hierarchy of activities, the scope and boundaries of interactions, and establishment of an appropriate economic environment at the macro level through a variety of activities. Among these activities the following may be mentioned: natural resources market creation; introduction of ecological taxes, payments and fines for environment pollution; introduction of the international environmental standards and regulations; intensification of environmental control; environmentally adjusted pricing, especially for natural resource intensive industries; trading of pollution rights, etc. [8].

Science and technology, scientific and technological progress, play significant role in social development ensuring. These two factors determine the economy's level of innovation and the opportunities to reduce or to eliminate pollution. Clearly, the development of science, technology, production, and modern information technology require certain resource base, which means the initial level of national wealth that ensures the conditions and largely determines the effectiveness of social development which is heavily determined by state of socio-economic and political and legal institutions [12,25].

The challenges of public system modernization are broader than the aspects of economic modernization, since it involves the social and environmental development components. Ivan Yanzul's four principles showing complexity, difficulty, and long-term nature of challenges facing Russian society. These principles could be applied to solve public modernization issues [26]:

1. For the benefit of purely material welfare of people, the widest possible moral development, and particularly the integrity in its comprehensive meaning, is required.

2 . The integrity nation is not only morally strong, but also economically strong. The human moral instinct should be based on empathy and sympathy.

3. Only simultaneous development of education and strengthening the morality and integrity can considerably raise the general level of culture.

4. Neither of the greatest wealth-generating virtues of the state is as essential as integrity (fulfillment of commitments; respect for others' property and rights, existing legislation and moral rules). No matter how many schools have built in Russia, but until the importance of integrity is low the improvement in welfare cannot be expected.

\section{Conclusion}

In the Russian Federation, it is an urgent need in systemic modernization of social development. Strategic orientations of Russia should include not only economic, but also other key aspects of societal life. In turn it would ensure a sustainable growth, aimed at improving the quality of life of present and future generations. The sustainable growth will facilitate the lengthy managed democratic process of social transformation at global, regional, and local level.

The «systemic modernization concept» involves various key aspects of societal life. There is a number of reasons for immediacy of systemic modernization problem in the Russian Federation. The key issue in deliberate institutional changes in public administration and public service is a necessity to ensure the consistency between transformation of the institutional system and objective needs of society in different stages of economic and social development. Analysis of main economic indicators characterizing domestic economy's level of development and structure for past two decades confirms the assumptions about the reasons of immediacy of domestic economy's systemic modernization problem. Ivan Yanzul's four principles showing complexity, difficulty, and long-term nature of challenges facing Russian society, could be applied to solve public modernization issues, as modernization of public system issues are broader than the aspects of economic modernization.

\section{References}

[1] Eisenstadt, S.N., 1967. Modernization, Growth and Diversity. Englewood Cliffs,NJ: Prentice Hall.

[2] Gibbons, D.S., De Konincke, R., Hasan,I., 1980. Agricultural modernization, poverty and inequality, Saxon House, Farnborough.

[3] Moore, Barrington. 1966. Social Origins of Dictatorship and Democracy: Lord and Peasant in the Making of the Modern World. Beacon Press, Boston.

[4] Walter J., Gonzalez, C.S., 1995. Cambio tecnológico y redes formales e informales en empresas argentinas. FLACSO-México. Perfiles Latinoamericanos, 4 (7).

[5] Jänicke, M., 1984. Umweltpolitische Prävention als ökologische Modernisierung und Strukturpolitik, Wissenschaftszentrum Berlin (WZB) (Hrsg.): IIUG discussion papers, Berlin.

[6] Jóhannesson, I. Á., 2006. Strong, independent, able to learn more .... Inclusion and the construction of school students in Iceland as diagnosable subjects. Discourse: Studies in the Cultural Politics of Education.

[7] Feraru, G.S., 2012. Ways of Russian economy's system modernization development. Modern issues and prospective of innovation economy development management. International scientific and practical conference proceedings, Belgorod (In Russian).

[8] Feraru, G.S. 2008. Methodology of sustainable development of the timber industry complex enterprises as ecological and economic systems: The author's abstract of the dissertation ... Doctor of Economic Sciences, Vologda (In Russian).

[9] Lesage, D., Van De Graaf, T. and Westphal, K., 2010. Global Energy Governance in a Multipolar World. Farnham, Ashgate. 
[10] L. Shevtsova, 2013. Russia XXI: The Logic of Suicide and Rebirth. Carnegie Moscow Center, Moscow.

[11] Khrolenko, A.T., 1996. Self-management Economics, Moscow (In Russian).

[12] Tarkhova, A.V., 2011. Modernization component of the anti-crisis regulation of the Russian economy: the author's abstract of the thesis.... Candidate of Economic Sciences, Vladikavkaz (In Russian).

[13] Boldyrev, S.N., 2012. Institutional changes in the economy as a determinant of the national Russian economy modernization: the author's abstract of the thesis ... Candidate of Economic Sciences, Tambov (In Russian).

[14] Samkhanova, L.V., 2011. Formation of small business development regional policy in the conditions of economic modernization: the author's abstract of the thesis ... The candidate of economic sciences, Kislovodsk (In Russian).

[15] Vasilkovskiy, I.V., 2011. Administrative decisions in the field of economic modernization: administrative and legal aspect: the author's abstract of the thesis ... Candidate of Juridical Sciences, Moscow (In Russian).

[16] Nistotskaya, M., Khakhunova, A., Dahlström, C., 2015. Expert Survey on the Quality of Government in Russia's Regions: Dataset. University of Gothenburg: The Quality of Government Institute, Gothenburg.

[17] Knutsen, C. H., 2013. Democracy, state capacity, and economic growth. World Development, 43:118.
[18] Acemoglu, D., Ticchi, D., and Vindigni, A., 2011. Emergence and persistence of inefficient states. Journal of the European Economic Association, 9(2).

[19] Fukuyama, F., 2013. What is governance? Technical Report Working Paper 314, Center for Global Development.

[20] Evans, P., Rauch, J. E., 1999. Bureaucracy and Growth: A Cross-National Analysis of the Effects of "Weberian" State Structures on Economic Growth Author(s): Source: American Sociological Review, American Sociological Association, 64 (5).

[21] Federal State Statistics Service: http://www.gks.ru

[22] Deruzhinsky, G.V., 2009. Management of investment processes in the conditions of region transport complex modernization: methodological approaches, models, tools: the author's abstract of the thesis ... Doctor of Economic Sciences, Rostov-onDon (In Russian).

[23] Mezentseva, E.S., 2009.The strategy of small business adaptive development in the conditions of region's economy modernization: the author's abstract of the thesis ... of the candidate of economic sciences, Ekaterinburg (In Russian).

[24] Besley, T. and Persson, T., 2011. Pillars of Prosperity: The Political Economics of Development Clusters. Princeton University Press.

[24] Henderson, J.; Hulme, D.; Jalilian, H.; Phillips, R., 2007. Bureaucratic Effects: 'Weberian' State Agencies and Poverty Reduction. Sociology, 41 (3).

[25] Stoykova, N. Ya., 1911. Memories of I. I. Yanzul about the experience and seen in 1864-1909. Electrotypography, St. Petersburg. v. 2 (In Russian). 